\title{
The rs2200733 variant on chromosome 4q25 is a risk factor for cardioembolic stroke related to atrial fibrillation in Polish patients
}

\section{Polimorfizm rs2200733 na chromosomie 4q25 jest czynnikiem ryzyka udaru sercowozatorowego zwiqzanego z migotaniem przedsionków w populacii polskiej}

Marcin Wnuk', Joanna Pera ${ }^{1 *}$, Jeremiasz Jagiełta', Elżbieta Szczygieł', Antoni Ferens', Karolina Spisak', Paweł Wołkow², Maria Kmieć', Jacek Burkot', Joanna Chrzanowska-Waśko', Woiciech Turaj', Agnieszka Stowik'

'Department of Neurology, Jagiellonian University College of Medicine, Krakow

2Department of Pharmacology, Jagiellonian University College of Medicine, Krakow

\begin{abstract}
Background and purpose: A few single nucleotide polymorphisms (SNPs) on chromosome 4q25, associated with atrial fibrillation (AF), are risk factors for ischaemic stroke. We studied the significance of the SNP rs2200733 on chromosome 4q25 in different types of cardioembolic (CE) stroke. Material and methods: We genotyped 428 controls and $301 \mathrm{CE}$ stroke patients, among whom 197 (65.4\%) presented with high risk sources of embolism (CE stroke related to $\mathrm{AF}$ ) and 104 with medium risk sources (CE stroke unrelated to AF). The SNP rs2200733 was analysed using realtime polymorphism chain reaction.

Results: Both univariate and multivariate regression analyses showed that the studied variant affected risk of all CE strokes or $\mathrm{CE}$ strokes related to $\mathrm{AF}$ in recessive and additive models. The two types of CE stroke differed significantly in demographics and distribution of vascular risk factors.

Conclusions: The SNP rs2200733 on chromosome 4q25 is a risk factor for $\mathrm{CE}$ stroke related to $\mathrm{AF}$ only.
\end{abstract}

Key words: cardioembolic stroke, atrial fibrillation, polymorphism.

\section{Streszczenie}

Wstęp i cel pracy: Kilka polimorfizmów na chromosomie 4q25, związanych z migotaniem przedsionków, jest czynnikami ryzyka udaru niedokrwiennego mózgu. Przeanalizowano znaczenie polimorfizmu rs2200733 na chromosomie 4 q25 w różnych typach udaru sercowozatorowego.

Materiał i metody: Badany polimorfizm oznaczono u 428 osób tworzących grupę kontrolną oraz u 301 chorych na udar sercowozatorowy, spośród których 197 (65,4\%) miało źródło zatorowości o dużym ryzyku (udar sercowozatorowy związany z migotaniem przedsionków), a 104 o pośrednim ryzyku (udar sercowozatorowy niezwiązany z migotaniem przedsionków). Do analizy polimorfizmu rs2200733 wykorzystano reakcję łańcuchową polimerazy DNA z analizą ilości produktu w czasie rzeczywistym.

Wyniki: Zarówno jedno-, jak i wieloczynnikowa analiza regresji logistycznej wykazały, że badany wariant wpływał na ryzyko wystąpienia wszystkich udarów sercowozatorowych oraz tych związanych z migotaniem przedsionków w modelach recesywnym i addytywnym. Dwa typy udaru sercowozatorowego różniły się w zakresie czynników demograficznych oraz rozkładu naczyniowych czynników ryzyka.

Correspondence address: Marcin Wnuk, Uniwersytet Jagielloński, Collegium Medicum, Katedra i Klinika Neurologii, ul. Botaniczna 3, 31-503 Kraków, e-mail:marcin.a.wnuk@gmail.com

Received: 25.08.2010; accepted: 19.02.2011

*These authors contributed equally to the study 
Wnioski: Polimorfizm rs2200733 na chromosomie 4q25 jest czynnikiem ryzyka jedynie udaru sercowozatorowego związanego z migotaniem przedsionków.

Słowa kluczowe: udar sercowozatorowy, migotanie przedsionków, polimorfizm.

\section{Introduction}

A recent genome-wide association study (GWAS) revealed that a haplotype block on chromosome 4q25 predisposed to atrial fibrillation (AF) [1]. In this block, two variants were in strong linkage disequilibrium and defined three haplotypes. One of them, rs2200733, increased the risk of AF by 1.72, and the second one, rs10033464, by 1.39. The association of the rs2200733 variant with $\mathrm{AF}$ was then confirmed in several replication populations [2].

The significance of the rs2200733 variant as a risk factor for stroke was studied in another large GWAS [3]. The results from this study, combined with the data from four replication European populations, showed that the $\mathrm{T}$ allele of the rs2200733 variant reached GWAS significance as a risk factor for all strokes without considering aetiology, cardioembolic (CE) or non-CE strokes [3].

In the previous study performed in co-operation with investigators from 5 different countries and including 4190 ischaemic stroke patients and 3740 controls, we replicated the association of the single nucleotide polymorphism (SNP) rs2200733 with atrial fibrillation and ischaemic stroke of cardioembolic aetiology [4]. In the present case-control study, we evaluated the role of the rs2200733 variant on chromosome 4q25 in patients with cardioembolic stroke related or unrelated to AF. So far such division of cardioembolic stroke patients has never been performed according to the genetic risk factors.

\section{Material and methods}

Consecutive patients with $\mathrm{CE}$ stroke, diagnosed according to the TOAST criteria [5], admitted to the Stroke Unit, Department of Neurology, University Hospital in Cracow, between 2005 and 2010, were included in the study.

Information on potential cardiac sources of embolism was based on previous medical documentation or investigations performed during the current hospitalization (ECG $-100 \%$, carotid ultrasound $-71 \%$, echocardio- graphy -62\%). There were 197 cases with $\mathrm{AF}$ (65.4\%). In the remaining 104 cases, $\mathrm{CE}$ stroke was diagnosed because of low ejection fraction due to ischaemic heart disease $(n=72)$, myocardial infarction $(n=13)$, atrial septal defect $(n=12)$ or bioprosthetic cardiac valve $(n=7)$ (CE stroke unrelated to AF).

Controls were collected as described previously [6]. Information on demographics and vascular risk factors from patients and controls was collected as described previously [6]. The rs2200733 polymorphism was identified using real-time polymorphism chain reaction RT-PCR [7]. This study was performed according to the Helsinki Declaration with approval of the local Ethical Committee. All individuals gave informed consent.

Comparisons between the groups were made with $\chi^{2}$ test or Student's $t$-test. The Hardy-Weinberg equilibrium was tested by the $\chi^{2}$ method. The association of the rs2200733 genotypes with the risk of CE stroke was tested using univariate and multivariate logistic regression analyses (SPSS 10 for Windows).

\section{Results}

The study included $301 \mathrm{CE}$ stroke patients and 428 controls. There was no deviation from Hardy-Weinberg equilibrium regarding the SNP rs2200733 in the studied groups.

Patients with $\mathrm{CE}$ stroke related to $\mathrm{AF}$ as compared to others were older, more often male and had different distribution of the vascular risk factors (Table 1).

All CE stroke patients had significantly higher prevalence of the genotypes with the T allele (CC -189 [62.8\%], CT - 101 [33.6\%], TT - 11 [3.7\%]) than controls $(\mathrm{CC}-307$ [71.7\%], CT -109 [25.5\%], TT $-12[2.8 \%])\left(\chi^{2}, p<0.05\right)$. The distribution of the polymorphism was significantly different between $\mathrm{CE}$ strokes with AF (CC - 116 [58.9\%], CT - 70 [35.5\%], TT $-11[5.6 \%])$ and without $\mathrm{AF}(\mathrm{CC}-73$ [60.2\%], CT - 31 [29.8\%], TT - 0) $\left(\chi^{2}, p<0.05\right)$.

Both univariate and multivariate regression analyses revealed that the $\mathrm{T}$ allele of the studied variant af- 
Table 1. The profile of risk factors in patients with cardioembolic stroke related and unrelated to atrial fibrillation

\begin{tabular}{|lccc|}
\hline & $\begin{array}{c}\text { Cardioembolic stroke } \\
\text { related to atrial fibrillation } \\
(\mathbf{N}=\mathbf{1 9 7})\end{array}$ & $\begin{array}{c}\text { Cardioembolic stroke } \\
\text { unrelated to atrial fibrillation } \\
\mathbf{( N = 1 0 4 )}\end{array}$ & OR (95\% Cl)* \\
\hline Hypertension & $168(85.3 \%)$ & $75(72.1 \%)$ & $2.24(1.25-4.01)^{* *}$ \\
\hline Diabetes mellitus & $69(35 \%)$ & $20(19.2 \%)$ & $2.26(1.28-4.00)^{* *}$ \\
\hline Ischaemic heart disease & $147(74.6 \%)$ & $67(64.4 \%)$ & $1.62(0.97-2.71)$ \\
\hline Myocardial infarction & $35(17.8 \%)$ & $46(44.2 \%)$ & $0.28(0.17-0.49)^{* *}$ \\
\hline Hypercholesterolaemia & $79(40.1 \%)$ & $64(61.5 \%)$ & $0.41(0.25-0.67)^{* *}$ \\
\hline Smoking*** & $23(11.7 \%)$ & $41(39.4 \%)$ & $0.19(0.11-0.35)^{* *}$ \\
\hline
\end{tabular}

*OR (95\% CI); logistic regression analysis adjusted for age and gender

*** $p<0.05$

***26 (13.2\%) patients with cardioembolic stroke related to atrial fibrillation and 12 (11.5\%) unrelated to atrial fibrillation did not give information on their smoking habits

Table 2. Relative risk of cardioembolic (CE) ischaemic stroke in carriers of the SNP rs2200733

\begin{tabular}{|c|c|c|c|c|c|c|}
\hline & Crude OR* & $p$-value & $\begin{array}{l}\text { OR adjusted for all } \\
\text { studied risk factors** }\end{array}$ & p-value & $\begin{array}{l}\text { OR adjusted for all } \\
\text { studied risk factors** } \\
\text { except for AF }\end{array}$ & $p$-value \\
\hline \multicolumn{7}{|l|}{ All CE strokes } \\
\hline dominant model & $1.31(0.57-3.02)$ & 0.52 & $0.61(0.17-2.27)$ & 0.47 & $1.53(0.49-4.80)$ & 0.47 \\
\hline recessive model & $1.50(1.10-2.06)$ & 0.01 & $1.37(0.83-2.67)$ & 0.22 & $1.64(1.06-2.53)$ & 0.025 \\
\hline additive model & $1.40(1.06-1.83)$ & 0.01 & $1.20(0.78-1.87)$ & 0.41 & $1.51(1.04-2.21)$ & 0.03 \\
\hline \multicolumn{7}{|c|}{$\mathrm{CE}$ strokes related to $\mathrm{AF}$} \\
\hline dominant model & $2.05(0.89-4.74)$ & 0.09 & $\mathrm{~N} / \mathrm{A}$ & - & $2.74(0.78-9.65)$ & 0.11 \\
\hline recessive model & $1.77(1.24-2.52)$ & 0.002 & $\mathrm{~N} / \mathrm{A}$ & - & $2.14(1.27-3.62)$ & 0.004 \\
\hline additive model & $1.64(1.22-2.21)$ & 0.001 & $\mathrm{~N} / \mathrm{A}$ & - & $1.95(1.25-3.04)$ & 0.003 \\
\hline \multicolumn{7}{|c|}{$\mathrm{CE}$ strokes unrelated to $\mathrm{AF}$} \\
\hline dominant model & $\mathrm{N} / \mathrm{A}$ & - & $\mathrm{N} / \mathrm{A}$ & - & $\mathrm{N} / \mathrm{A}$ & - \\
\hline recessive model & $1.08(0.67-1.73)$ & 0.76 & $\mathrm{~N} / \mathrm{A}$ & - & $1.24(0.67-2.31)$ & 0.50 \\
\hline additive model & $0.95(0.62-1.46)$ & 0.82 & $\mathrm{~N} / \mathrm{A}$ & - & $1.07(0.61-1.89)$ & 0.80 \\
\hline
\end{tabular}

*Odds ratios $(O R)$ with $95 \%$ confidence intervals

**Age, gender, hypertension, diabetes mellitus, ischaemic heart disease, myocardial infarction, hypercholesterolaemia, smoking and atrial fibrillation (AF)

$N / A$ - non-applicable (due to the lack of TT genotype in CE strokes unrelated to AF)

fected the risk of all $\mathrm{CE}$ strokes or $\mathrm{CE}$ strokes related to $\mathrm{AF}$ in recessive and additive models of inheritance (Table 2).

\section{Discussion}

Based on our data, we suggest that patients with the two types of $\mathrm{CE}$ stroke, with high or medium risk sources of cardioembolism, should be considered separately because they present with different distribution of vascular and genetic risk factors. In the present study it was also revealed that patients with $\mathrm{CE}$ stroke related or unrelated to AF differed in terms of demographic presentation. To our knowledge, this is the first study showing significant heterogeneity among $\mathrm{CE}$ stroke patients which, according to the TOAST criteria, belong to one subgroup. Previous studies showed only a difference in the distribution of vascular risk factors among subtypes of ischaemic stroke based on the TOAST classification $[8,9]$.

The TOAST criteria are useful in respect of prophylaxis of ischaemic stroke. Cardioembolic stroke can be diagnosed in a wide range of cardiac disorders: from 
atrial fibrillation, through recent myocardial infarction and infective endocarditis, to congestive heart failure with low ejection fraction and cardiomyopathy. All patients with these potential cardioembolic conditions should be treated with antithrombotic drugs in contrast to patients with other ischaemic stroke aetiologies in whom antiplatelet drugs represent the first line of treatment.

However, when investigating the pathophysiology and genetics of ischaemic stroke, the TOAST system seems to be outdated. Even in our research the studied polymorphism was not an independent risk factor for stroke until all CE stroke patients were divided into two subgroups, related or unrelated to AF. It is worth considering these two subtypes of $\mathrm{CE}$ stroke separately in future studies concerning pathophysiology and genetic risk factors of stroke.

In conclusion, we revealed that the $\mathrm{T}$ allele of the rs2200733 variant was a risk factor for CE stroke specifically related to AF. Although the TOAST diagnostic system in stroke genetic studies has only modest intrarater reliability [10], it is still used in the research concerning genetic risk factors for stroke. Thus, we recommend that patients with CE stroke should be divided into at least two separate subgroups on the basis of the genetic and clinical differences shown in our study. However, because of the relatively small group size, future studies are needed to confirm our results.

\section{Conclusions}

The SNP rs2200733 on chromosome 4q25 is a risk factor for $\mathrm{CE}$ stroke related to AF only.

\section{Disclosure}

Wojciech Turaj serves as an editor of Neurologia i Neurochirurgia Polska. Other authors declared no conflict of interest.

\section{References}

1. Gudbjartsson D.F., Arnar D.O., Helgadottir A., et al. Variants conferring risk of atrial fibrillation on chromosome $4 \mathrm{q} 25$. Nature 2007; 448: 353-357.

2. Kääb S., Darbar D., van Noord C., et al. Large scale replication and meta-analysis of variants on chromosome $4 \mathrm{q} 25$ associated with atrial fibrillation. Eur Heart J 2009; 30: 813-819.

3. Gretarsdottir S., Thorleifsson G., Manolescu A., et al. Risk variants for atrial fibrillation on chromosome $4 \mathrm{q} 25$ associate with ischemic stroke. Ann Neurol 2008; 64: 402-409.
4. Lemmens R., Buysschaert I., Geelen V., et al. Replication of association between variant on $4 \mathrm{q} 25$ with atrial fibrillation and cardioembolic stroke. Stroke 2010; 41: 1850-1857.

5. Adams H.P. Jr, Bendixen B.H., Kappelle L.J., et al. Classification of subtype of acute ischemic stroke. Definitions for use in a multicenter clinical trial. TOAST. Trial of Org 10172 in Acute Stroke Treatment. Stroke 1993; 24: 35-41.

6. Slowik A., Dziedzic T., Turaj W., et al. A2 alelle of GpIIIa gene is a risk factor for stroke caused by large-vessel disease in males. Stroke 2004; 35: 1589-1593.

7. O'Connor L., Glynn B. Recent advances in the development of nucleic acid diagnostics. Expert Rev Med Devices 2010; 7 : 529-539.

8. Schulz U.G., Rothwell P.M. Differences in vascular risk factors between etiological subtypes of ischemic stroke: importance of population-based studies. Stroke 2003; 34: 2050-2059.

9. Pinto A., Tuttolomondo A., Di Raimondo D., et al. Cerebrovascular risk factors and clinical classification of strokes. Semin Vasc Med 2004; 4: 287-303.

10. Gordon D.L., Bendixen B.H., Adams H.P. Jr, et al. Interphysician agreement in the diagnosis of subtypes of acute ischemic stroke: implications for clinical trials. The TOAST Investigators. Neurology 1993; 43: 1021-1027. 